\title{
DO CUSTOMERS ADOPT AUTO IJARAH FINANCING? THE CASE OF PAKISTAN
}

\author{
Syed Ali Raza ${ }^{1}$, Bushra Umer ${ }^{1}$, Muhammad Ali2 ${ }^{*}$, and Muhammad Ashfaq ${ }^{3}$ \\ ${ }^{1}$ Department of Management Sciences, IQRA University, Karachi 75300, Pakistan \\ ${ }^{2}$ Department of Accounting and Finance, Institute of Business Management (IoBM), \\ Korangi Creek, Karachi, Pakistan \\ ${ }^{3}$ IUBH University of Applied Sciences, Mülheimer Straße 38, \\ 53604 Bad Honnef, Germany
}

*Corresponding author: alisaleem_01@yahoo.com

Published online: 1 December 2021

To cite this article: Raza, S. A., Umer, B., Ali, M., \& Ashfaq, M. (2021). Do customers adopt auto ijarah financing? The case of Pakistan. Asian Academy of Management Journal, 26(2), 75-100. https://doi.org/10.21315/aamj2021.26.2.4

To link to this article: https://doi.org/10.21315/aamj2021.26.2.4

\begin{abstract}
The present study examines the factors affecting customer intention to use auto financing (ijarah) in Pakistan. The research framework is constructed based on the theory of reasoned action, which explains behavioural intention and its determinants. The study incorporates the participation of 350 potential customers of auto ijarah in Pakistan. Data analysis was conducted with structural equation modelling (SEM), assessing the measurement, and structural model. The outcome indicates that attitude, perceived cost benefits, Sharia compliance, religious orientation, and subjective norm are the significant predictors of customer intentions. We also found a statistically insignificant association between awareness and customer intentions. The results hold significance for the Islamic banking and financial service providers. This study provides a comprehensive understanding of the factors that contribute to the adoption of auto ijarah among potential Islamic bank customers.
\end{abstract}

Keywords: Islamic banks, auto ijarah, customer intention, Sharia compliance, Pakistan

(C) Asian Academy of Management and Penerbit Universiti Sains Malaysia, 2021. This work is licensed under the terms of the Creative Commons Attribution (CC BY) (http://creativecommons. org/licenses/by/4.0/). 


\section{INTRODUCTION}

Globally, Islamic banking and finance (IBF) are among the emergent industries which rely on Sharia-compliant principles of Islamic laws. Currently, financial institutions based on Islamic principles are operating in more than 75 countries. Likewise, the prevention of riba or usury (interest), the financial system in Islam also proscribes activities inclusive of uncertainty, gambling, and speculation. It promotes risk-reward sharing in financial services and products. In the banking system, the Sharia principles were established in the 1960s with the initiation of the first modern Islamic bank in Egypt by Ahmad Elnaggar followed by the foundation of Islamic Development bank in 1975 with Islamic principles in banking practices. ${ }^{1}$ The growth of the Islamic banking industry has been reflected in a diverse range of Sharia-based financial products and services and investment opportunities in the Middle East and Asia. Whereas Egypt, Indonesia, and Malaysia are considered pioneering countries in this regard (Awan \& Azhar, 2014). The assets of Islamic finance sector which stood at $\$ 2$ trillion in 2016 are projected to increase to $\$ 3.8$ trillion by the year 2022, whereas Malaysia, United Arab Emirates, and Bahrain continue to dominate the sector (Ahmadova, 2019).

From Pakistan's perspective, the industry of Islamic banking has been growing at a rapid pace since its inception. From 1977 to 1980, the Council of Islamic Ideology proposed concrete steps to introduce the Islamic financial system. The fundamental objective of Islamic banking is to stimulate monetary offerings to eliminate interest ( $r i b a$ ) from the economy. In 2002, the first Islamic banking license had been issued by the State Bank of Pakistan and the provision of developing Sharia-compliant products and services had been legislated. Currently, the Islamic banking industry constitutes five full-fledged Islamic banks, 21 Islamic banking institutions, and 16 conventional banks that have operated standalone Islamic banking windows.

In contrast, the branch network of Islamic banks comprises 2,589 branches. Presently, Islamic banking assets reached 2,334 billion as of March 2018. The market share of Islamic banking assets and their deposits by the end of March 2018 stood at $13.5 \%$ and $14.6 \%$, respectively (SBP Report, 2018). ${ }^{2}$

\section{A Brief Overview of the Auto Sector in Pakistan}

According to Invest Pakistan report on the auto sector (2020), ${ }^{3}$ Pakistan is considered the sixth largest world economy population. As of 2018, the majority of the population falls under middle-class income. The middle-class population can be categorised as middle-class individuals (102 million approximately) 
and middle-class households (17 million approximately). The report further revealed that Pakistan's automobile industry contributes Rs.30 billion in terms of duties and taxes along with $2.8 \%$ to overall gross domestic product (GDP). The automobile industry of Pakistan is dominated by some foreign companies, namely, Honda, Toyota, Suzuki, and local companies. In Pakistan Stock Exchange (PSX), the listed automobile companies include Ghani Automobile, Pak-Suzuki, Atlas Honda Ltd., Hinopak Motor, Sazgar Eng, Dewan Motors, Al-Ghazi Tractors, Ghandara Nissan, Ghandara Ind., Ghandara Diesel, Honda Atlas Cars XD, Indus Motors Co., and Millat Tractors. ${ }^{4}$ This industry mainly deals with cars, tractors, buses, motorcycles, trucks pick-ups, and jeeps. More precisely, the broad level of market dynamics and structure of Pakistan's auto industry includes automobile companies, automotive parts manufacturing, passenger car markets, and manufacturing and assembling units. However, the auto industry of Pakistan is a mixture of imported and locally manufactured cars. Among other Asian countries, Pakistan has shown the fastest growth in domestic demand and reported $171 \%$ of production from 2014 to 2018. Due to this, Pakistan launched a reform policy for the auto industry development on 19 March 2016. The policy's salient features include tax incentives for new assembling plants, lower investment restriction, friendly import policy, the research institute's foundation for the automotive industry, and vehicle financing by commercial banks. In response, Pakistan experienced a good response from various car assemblers and manufacturers.

Additionally, an average of $\$ 50$ million of foreign direct investment (FDI) was received in the auto sector from 2008 to 2018. Not only had this, but the new investment in the auto industry also brought technological advancement to safeguard the natural environment. The agreement between China and Pakistan for the China-Pakistan Economic Corridor (CPEC) has also increased the demand for vehicles in Pakistan. Similarly, online public transport companies (e.g., Uber, Careem, Air-Lift, Swvl, and Bykea) raised pressure on the vehicle industry to meet local demand.

\section{Auto Ijarah Financing in Pakistan}

Islamic banking products, like ijarah financing, must comply with Sharia regulations. But, there is still a conflict between Sharia scholars to what extent Islamic auto ijarah follows the true spirit of Islamic ideology. The debate somehow creates confusion among the potential customers of Islamic bank customers. The argument is that Sharia principles, in theory provide clear guidelines about auto financing. However, some Sharia scholars disagree with the Islamic banks and their practices on Islamic auto financing. The two schools of thoughts, 
whether auto ijarah is a fully Sharia compliance or not has created confusion among Muslim customers to adopt ijarah financing. Bhatti (2020a) and Bhatti and Md Husin (2019) explored Islamic finance's legal aspects and recommended its operational mechanism to be Sharia compliance. Further, earlier studies on Islamic finance unanimously agreed that there exists a need for more empirical evidence in the literature (Chaudhury \& Bhatti, 2017). To understand the needs of Islamic products, a wide range of Sharia-compliant financing modes are offered by Islamic banks of Pakistan, incorporating murabaha, musharaka, musawama, ijarah, salam, and istisna (Ali et al., 2015). Sharia-compliant auto financing (ijarah/leasing) is among the predominant products. It is the asset-based financing contract in which the usufruct is transferred from the asset owner to another person for a decided period and consideration. The product structure represents the bank as a lessor (i.e., owner or $m$ ' $_{\text {jir }}$ ) which provides the asset for use against the periodic rentals to avail the lease benefits to the lessee (i.e., user or musta jir). Under Islamic principles, the rights, risks, and liabilities related to asset ownership persist with the owner while all usage-related rights, risks, and liabilities persist with the user. Under the Islamic financial system guidelines, rental payments are charged against the usage of the asset. In the case of stealing and destruction, the rentals payment contract becomes void (Usmani, 2001).

In earlier literature, the attitude of the customers towards a product and the influence they encountered from society, family, and peers are the prominent factors for determining the behavioural intentions towards the adoption of Sharia-compliant products and services (Taib et al., 2008). Further, several aspects for preferring Islamic banking products were highlighted by Nawi et al. (2013) for the adoption of Islamic banking in Malaysia. Moreover, Bizri (2014) found that compliance with Sharia, knowledge of Sharia-compliant financing modes, financing cost, service quality, and availability of Islamic banks persuade customers to use Shariacompliant products and services in Lebanon. Moreover, Ali et al. (2015) while examining the reasons that influenced the customer's intentions to adopt Shariacompliant personal financing in Pakistan suggest that religious beliefs support from the government, and cost of Islamic personal financing are the significant predictors of customer's intention whereas customer's attitude and social influence showed a positive but insignificant association with the customers' intentions. Auto ijarah also had been studied in Pakistan and the favourable attitude of customers was observed towards auto ijarah who avail the ijarah facility from Islamic banks, and the demographic factors affect the perception of customers about Sharia compliance and service quality (Ehsan et al., 2018). Chapra et al. (2018) do a comparative analysis for consumer preference between Islamic and conventional auto ijarah financing in Pakistan. The findings indicate that convenience is the primary determinant of ijarah preference over the traditional lease. In contrast, 
other factors including awareness, income, and perception also motivate customers to adopt Islamic auto financing.

Pakistan has the largest Muslim population among other religions in the country. The Muslims in Pakistan faced several challenges to get a loan and fulfil their financing need. In this context, individual perception of Islamic financial products varies and changes from one person to another (Ali et al., 2015). Due to uncertain auto market and political stability, a large number of potential auto ijarah customers become subside. Earlier studies suggest that a lack of information or awareness may negatively influence customer adoption of Islamic banking products (Raza et al., 2019). Similarly, religious orientation and Sharia aspect also play a significant role to adopt auto ijarah financing. It is also a noteworthy point that auto ijarah involves financial transactions such as monthly rental and interest payments. Therefore, an individual adopts auto ijarah financing based on the perceived costbenefit analysis.

The Islamic banking industry's financing and related assets sustained its growth trend and showed $6.4 \%$ growth and stood at Rs.1,284 billion by the end of March 2018 as compared to the last quarter of 2018 (Rs.1,207 billion). According to the mode-wise breakup of Islamic financing products, it is observed that the share of ijarah is $6.4 \%$ in overall financing. Therefore, following the reviewed literature, it is noted that extensive studies have been conducted to study customer's intention towards Islamic banking products in general globally. However, a limited number of studies endeavoured to understand why customers' intention to use auto ijarah specifically. As per our knowledge, in Pakistan's context, no such study has been conducted, which integrates the Theory of Reasoned Action (TRA) framework for understating factors that account for customer's intention towards the selection of auto ijarah.

Thus, based on the aforementioned observation and witnessing the growing demand for Sharia-compliant auto financing-ijarah among people in Pakistan, the present study aims to bridge the research gap that pertains to the findings on the factors that account for the intentions to select auto ijarah financing in Pakistan. The study contributes to Islamic finance literature by incorporating the TRA proposed by Fishbein and Ajzen (1975) to investigate the reasons that affect the intention of customers. The framework for the present study is developed through modifying the TRA model by adding four variables including "awareness of auto ijarah," "perceived cost benefits," "Sharia compliance," and "religious orientation." Thus, this study examines the effect of attitude, social influence, awareness of auto ijarah, perceived cost benefits, Sharia compliance, and religious orientation on customer's intention to select Sharia-compliant auto financing, i.e., ijarah. 
The present research embraces significance for the authorities of Islamic banks and financial institutions. The study outcomes establish the source for an in-depth understanding of the factors that determine the behavioural intentions of customers in the adoption process.

\section{LITERATURE REVIEW}

\section{Theoretical Background}

\section{Theory of Reasoned Action}

The TRA model was presented by Ajzen and Fishbein (1977) to establish the relationship between an individual's underlying beliefs, attitude, intentions, and behaviour. This model is widely applied for the determination of an individual's intention and prediction of behaviour (Fishbein et al., 1980). The theory assumed that the attitude and subjective norm determined the behavioural intention of individuals. To acquire a profound understanding of the essentials that contribute to shaping behaviour, it is vital to understand the beliefs held by a person and the influence of social surroundings.

\section{Why TRA?}

In behavioural studies, the TRA model attained significant attention among the researchers. In past, several studies used TRA model to assess its acceptability in various contexts (Amin et al., 2008; Taib et al., 2008; Lada et al., 2009; Ramayah et al., 2003; Ali et al., 2017a; Yu, 2012; Amin et al., 2011; Farhat et al., 2019; Razak \& Abduh, 2012). It is a well-known fact that the TRA framework consists of psychological and social factors, namely, attitude, social influence, and behavioural intention. Additionally, the TRA model has a more exceptional ability to include more elements and modify the framework. The argument is further supported by earlier studies (Lada et al., 2009; Ali et al., 2017a; Farhat et al., 2019; Aziz \& Chok, 2013) that modified the TRA model of additional factors. In sum, the TRA model is useful for predicting behavioural intention and has the flexibility to adjust according to the study context. In previous studies, it has been observed that behavioural intentions are predicted significantly by the TRA model. This implies that the TRA model has the potential to investigate individual intention in various study contexts. Our literature review also suggests that behavioural intention should be analysed in the presence of additional factors. For this reason, we incorporated awareness, religious orientation, and Sharia compliance as additional variables in 
the TRA model. The selection of new variables is based on the past literature and the relevancy of our research setting. We also found that additional variables and the TRA model's basic constructs showed mixed results. This may be due to the multiple reasons such as different study contexts, changes in demographics, sampling, and other methodological differences. Hence, this study examined the behavioural intention of customers to adopt auto ijarah financing in Pakistan.

\section{How does auto ijarah financing works?}

Ijarah financing facility offered by Islamic bank is termed as ijarah wa iqtina, i.e., to hire or purchase an asset. Ijarah is the term of an Islamic law that refers to provide an entity on rent. In Islamic jurisprudence, "Ijarah is a contract which enables possession of a particularly intended usufruct of a leased asset for a consideration" (Khan \& Bhatti, 2008). The ijarah contract includes the financing of equipment, automobile, or house by a bank to a customer against the rent for the period as per agreed terms and conditions between the bank and the lessee. Additionally, an individual undertaking was made at the time of contract which includes the clause that at the end of lease agreement tenure, the leased asset's ownership will be transferred to the lessee along with all the risks and benefits associated with it. However, this undertaking is excluded from the main contract to prevent it from becoming conditional (Usmani, 2001). Additionally, the modus operandi of auto ijarah financing is illustrated in Figure 1. The main steps for ijarah financing are as follows:

1. The bank customer approaches the supplier for asset selection and gains all available information about the desired asset.

2. The bank customer contacts the Islamic bank to purchase the desired asset and schedule lease payments.

3. The Islamic bank evaluates the fair market price and purchases the asset on cash after all essential requirements.

4. The Islamic bank received ownership of the asset from the supplier.

5. The Islamic bank offers lease payment to the customer and transfers the asset's rights of use and possession.

6. The customer is liable to pay the rental payment on the agreed payment schedule.

7. The Islamic bank attains assets in operating lease while the ownership is transferred to the bank customer under a finance lease. 


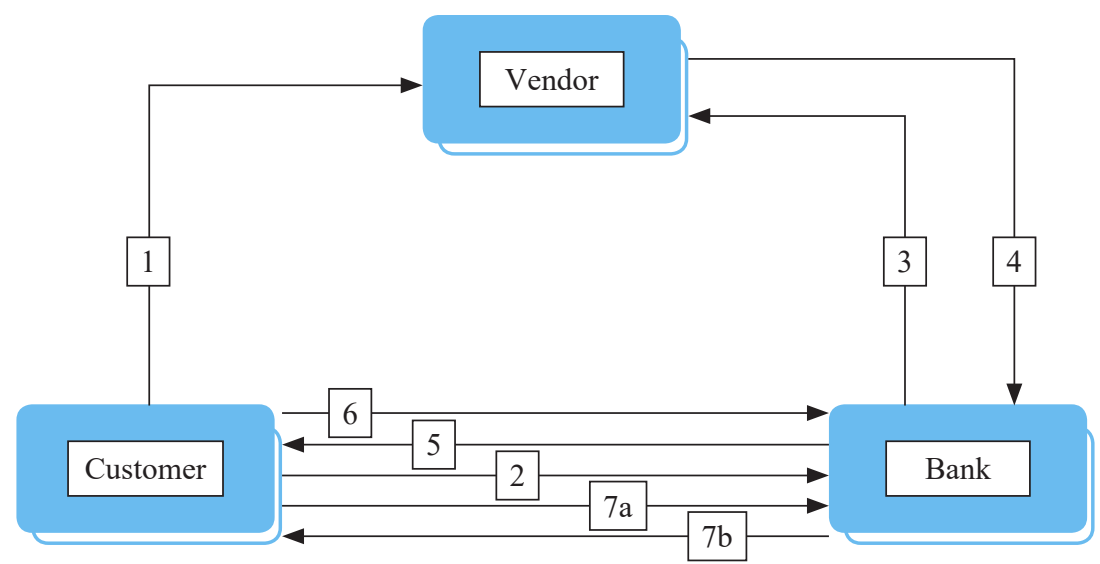

Figure 1. Modus operandi of auto ijarah financing Source: Khan et al. (2019)

It has appeared that conventional car financing and auto ijarah financing are the same. Thus, the most important differences concerning traditional auto financing and ijarah financing are discussed in Table 1.

Table 1

Conventional and Islamic ijarah financing

\begin{tabular}{|c|c|c|}
\hline Differences & Conventional auto financing & Islamic ijarah financing \\
\hline Terminology & Lease, lesser, and lesse & Ijarah, aajir, and ajir \\
\hline Rent & $\begin{array}{l}\text { Starts from the date of } \\
\text { agreement }\end{array}$ & $\begin{array}{l}\text { Starts when asset is delivered to } \\
\text { the customer }\end{array}$ \\
\hline Mode & Money is given as loan & Asset is bought on behalf of client \\
\hline Profit & $\begin{array}{l}\text { Interest is charged on loan } \\
\text { amount }\end{array}$ & $\begin{array}{l}\text { Rent is charged as share of the } \\
\text { bank in the asset }\end{array}$ \\
\hline Risk Management & $\begin{array}{l}\text { Risk of leased asset is } \\
\text { minimised through insurance }\end{array}$ & $\begin{array}{l}\text { Risk of leased asset is minimised } \\
\text { through takaful }\end{array}$ \\
\hline Penalty & $\begin{array}{l}\text { The bank charge penalty for } \\
\text { non-payment or late payment }\end{array}$ & $\begin{array}{l}\text { The bank charge penalty for non- } \\
\text { payment or late payment and pay } \\
\text { that amount as charity }\end{array}$ \\
\hline
\end{tabular}

Source: Razi (2014) 


\section{Hypotheses Development}

\section{Awareness}

Awareness of auto ijarah is defined by Al-Somali et al. (2009) as the awareness of the product's existence, its structure, features, and benefits. Also, awareness refers to the customer's amount of information regarding the products and services (Amin et al., 2008). The present study analyses the customer awareness of auto ijarah for existence, benefits, features, and differences with conventional financing operations. Multiple studies have examined the role of awareness in determining the purchase intentions of customers in the literature. Tenga et al. (2018) analysed customers' purchase intentions and the outcomes of the study indicated that the level of awareness among customers predict their usage intention. Moreover, the antecedents of usage intention of Islamic banking products were assessed by Ramli et al. (2018) and indicated that awareness is the primary antecedent of usage objective among customers. In the same way, Islam and Rahman (2017) explored the role of awareness in the adoption of Islamic banking products and services among Muslims in India. The results concluded that sound knowledge about product features and its benefits determine the intentions of customers. Contrary, the awareness of employees and their attitude towards the adoption of products and services from Islamic banks was studied by Buchari et al. (2015). The study concludes that there is no significant association between awareness and intentions of customers. Moreover, Rezai et al. (2012) studied the impact of awareness about the product on the consumption intention of customers. The findings of the study revealed that product awareness is the key indicator in predicting customers' intentions. The mixed results and the lack of findings in the context of auto ijarah are observed in earlier studies. Therefore, this study postulates the following hypothesis:

H1: Awareness will have a significant impact on intentions to select ijarah financing attitude.

According to the TRA framework, an individual's attitude refers to an assessment of positive and negative emotions to execute a particular behaviour. It is assumed that a positive attitude enhances the probability of individual behaviour (Ajzen \& Fishbein, 1977). Several studies have been conducted on customer attitude and provide empirical evidence of a significant relationship between customer attitude and intentions. Kaakeh et al. (2019) studied the adoption factors of Islamic banking in United Arab Emirates and the findings revealed that attitude has a direct and significant effect on customers' intentions. Similarly, the adoption of the Islamic card among Malaysian customers has been studied 
by Jamshidi and Hussin (2018). The findings concluded that attitude is the strongest predictor and determinant of the intention of customers. Similarly, a positive and significant association was found between customers' attitude and intentions to adopt Islamic banking by Kaawaase and Nalukwago (2017) while studying existing conventional bank customers' behaviours in Uganda. Similarly, a significant relationship between attitude and intention was reported by Taib et al. (2008). They concluded that students' intentions and the level of acceptance towards diminishing partnership home financing rely on their attitude. It has been found by Gopi and Ramayah (2007) while studying the online trading system in Malaysia that their positive attitude determines the intention of the customers. Bhatti and Md Husin (2019) also found a significant and positive relationship between attitude and intentions to use family takaful schemes by the Muslims in the United Arab Emirates. Still, a shred of insufficient empirical evidence is observed mainly in the context of auto ijarah financing. Therefore, the present study proposed the following hypothesis:

H2: Attitude will have a significant impact on intentions to select auto ijarah financing.

\section{Perceived cost-benefit}

According to Al-Ajmi et al. (2009), perceived cost benefits refer to customers' cost-benefit analysis in terms of contract terms, service charges, and monthly rentals offered by Islamic banks. This analysis can be positive or negative and relies upon the evaluation of customers. Multiple studies assessed the effect of the customers' perception of gaining cost benefits on their intentions to adopt Islamic banking products. Hoque et al. (2019) investigate the factors contributing to potential customers' intentions to select Islamic banks' products and services. The findings state that perceived potential benefits strengthen the behavioural intentions. Similarly, Jaffar and Musa (2016) studied the predictors of customers' intentions to adopt Islamic financing. The results indicate that perceived cost-benefits in terms of favourable terms, service charges, and monthly repayment have the strongest impact on customer intention. Likewise, Mansour et al. (2016) examined the effect of consumers' cost-benefits and purchase intention. The outcomes of the study indicated that the evaluation of incurred cost and benefits predicts their usage intention. Thus, given the mentioned studies, the present study postulates the following hypothesis:

H3: Perceived cost-benefit will have a significant impact on intentions to select ijarah financing. 


\section{Religious orientation}

Religious orientation refers to religion's role in influencing an individual's choices and activities (Reich et al., 1999). Islamic banks must follow Islamic principles based on Sharia and design the products under the guidelines provided. The banks' observance of these rules affects an individual's choice to opt for Islamic banking products. Bananuka et al. (2019) investigated the effect of religious orientation on potential customers' behavioural intentions to adopt Islamic banks products. The results of the study conclude that religious orientation is a significant predictor of customers intention. Likewise, Souiden and Rani (2015) state that the more a person is inclined towards religion and has faith on divine consequences, the more favourable the attitude and intentions towards Islamic banking products. Sulaiman (2003) also demonstrates that greater adherence to Sharia rules increases the possibility of an individual to use Islamic personal financing. Similarly, it is depicted by Metwally (1996) that religious orientation is the strongest and critical factor that drive the attitude towards Islamic banks and adoption of Islamic financial services. Omer (1992) found religious motives as the primary motivation to deal with Islamic financial institutions for their banking needs. Hanif et al. (2020a, 2020b) highlighted that Muslim customers are more inclined towards Sharia-based financial products. Therefore, the following hypothesis is proposed:

H4: Religious orientation will have a significant impact on intentions to select ijarah-financing Sharia compliance.

The word Sharia compliance is mainly used for Islamic financial products. In this study, we consider Sharia compliance as the customer perception that auto ijarah financing is free from elements prohibited by Sharia such as riba (interest), qimar (gambling), and gharar (uncertainty) outlined by the Holy Quran and Sunnah (Ahmad et al., 2008). Several studies have highlighted the importance of Sharia compliance and considered an important factor in predicting customer intention about Islamic finance (Kaakeh et al., 2019). Lee and Ullah (2011) study regarded Sharia compliance as a significant determinant to select Islamic banking. Their study found that a customer with a high perception of Sharia compliance about Islamic banks may switch to other banks if the violation of Sharia compliance occurs repeatedly. Similarly, Amin et al. (2014a) found that Sharia compliance contributes to accepting Islamic financial products in Malaysia. Another study of Amin et al. (2014b) argued that Sharia compliance satisfaction predicts customer intention to choose Islamic home financing. On the same token, Ali et al. (2017b) also found similar results; they suggest that Sharia compliance of a product is one of the significant predictors of customer's 
intention to select Islamic home financing in Pakistan. Wajdi Dusuki and Irwani Abdullah (2007) reported that customer's patronising behaviour about Islamic finance is mainly due to bank compliance with Sharia principles. On the other side, Saqib et al. (2016) study used Sharia compliance as a moderating factor between customer satisfaction and service quality in Islamic banks. Ali and Raza (2017) also employed Sharia compliance to predict Islamic bank customers satisfaction. Kaakeh et al. (2019) found a positive and significant relationship between Sharia compliance and customers intention towards Islamic banking in the United Arab Emirates. Hence, our study posits the following hypothesis.

H5: Sharia compliance will have a significant impact on intentions to select ijarah financing.

\section{Subjective norm}

Subjective norm is a primary construct of the TRA framework, which refers to the influence of societal pressure and social environment on individual's behavioural intentions, provoking or abstaining from specific behaviour. According to the assumptions of TRA, the subjective norm is the direct predictor of behavioural intention (Fishbein \& Ajzen, 1975). Chang (1998) states that an individual's behaviour is significantly impacted because of the subjective norm or social influence. It is evident from the study conducted by Hassan and Abbas (2019) on the determinants of Islamic insurance adoption that subjective norm or social impact significantly influences customers' behavioural intention. Also, Yaseen and El Qirem (2018) studied customers intentions for the adoption of e-banking services and identified subjective norm as the significant predictor of intention. Similarly, Gumel et al. (2015) studied Islamic home financing adoption and stated that the subjective norm component is the major factor in determining customers' behavioural intentions. Another study postulates that social pressure from other users, including family members, peers, and friends, predicts individuals' intention (Pelling \& White, 2009). In the literature, the mixed findings regarding the relationship between subjective norm and intentions of individuals have been reported. In some studies, no significant association was found between these constructs (Chau \& Hu, 2001; Lewis et al., 2003) whereas many studies have supported the statistical significance of subjective norm and behavioural intentions and highlighted it as a strong determinant of intentions among individuals (Ramayah et al., 2003; Yulihasri, 2004). Therefore, based on the past literature, the present study suggested the following hypothesis:

H6: Subjective norm will have a significant impact on intentions to select ijarah financing. 


\section{METHODOLOGY}

\section{Conceptual Framework}

As indicated in Figure 2, the model demonstrates the determinants that affect customers intention to use Sharia-compliant auto ijarah financing. The conceptual model comprises dependent and independent variables, including the intention to use auto ijarah financing as the dependent variable. In contrast, subjective norm, attitude, awareness, perceived cost-benefits, Sharia compliance, and religious orientation incorporated as independent variables.

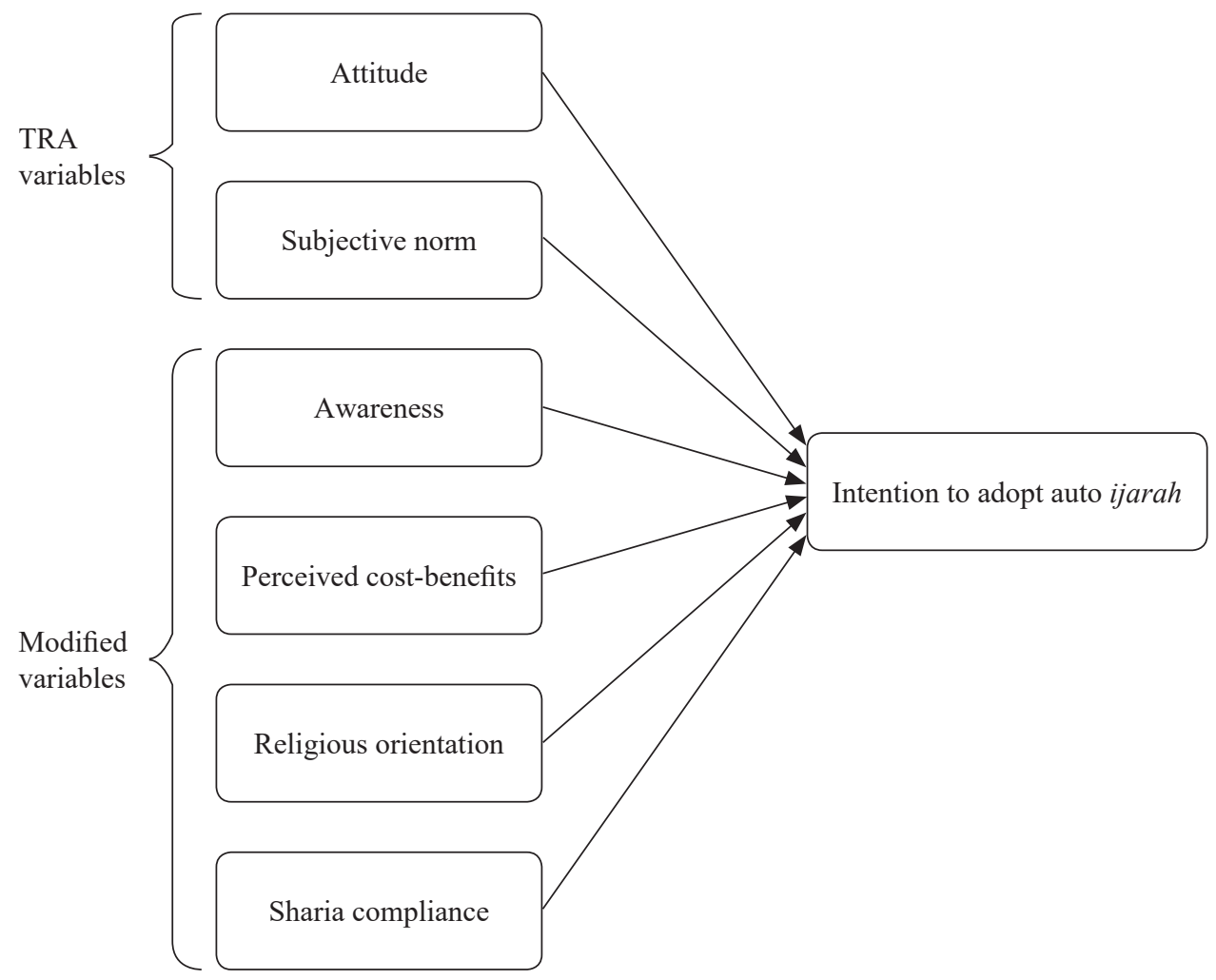

Figure 2. Conceptual framework

\section{Sample Size and Data Collection}

The current study pursues prospective customers of ijarah financing as a substitute for those who avail auto ijarah facility. Therefore, the target population comprises potential customers with intentions to avail ijarah financing from 
Islamic banks in Pakistan. A survey-based questionnaire was used to collect sample data using a 5-point Likert scale ranges from $1=$ strongly disagree to $5=$ strongly agree. A survey was conducted for obtaining the responses by sending the questionnaires to potential customers who have intentions to avail ijarah financing from Islamic banks in Pakistan. To confirm the sample size, we used guidelines from Comrey and Lee (1992) and a total of 350 respondents' data were gathered. The details of the respondents' profile for age, gender, employment status, and income are presented in Table 2.

Table 2

Profile of respondents $(N=350)$

\begin{tabular}{lcc}
\hline Demographic items & Frequency & Percentage \\
\hline Gender & 206 & 59 \\
$\quad$ Male & 144 & 41 \\
$\quad$ Female & & \\
Employment status & 33 & 9.4 \\
$\quad$ Government employee & 280 & 80 \\
$\quad$ Private employee & 21 & 6 \\
Semi-government employee & 16 & 4.6 \\
Other & & \\
Age & 128 & 36.6 \\
20-30 years & 161 & 46 \\
$31-40$ years & 61 & 17.4 \\
$41-50$ years & & \\
Income (in thousands PKR) & 82 & 23.4 \\
$30-40$ & 126 & 36 \\
$41-50$ & 93 & 26.6 \\
$51-60$ & 49 & 14 \\
Above 60 &
\end{tabular}

\section{Measurement Instrument}

All the measurement items were adapted from the literature. A total of 28 items were included in the questionnaire. The scale for the subjective norm, attitude, religious orientation, and intention to use auto ijarah financing were taken from the study of Amin et al. (2011). Likewise, Othman and Owen (2001) study was used for the items of Sharia compliance. Moreover, auto ijarah financing awareness is measured by using the scale adapted from Bashir (2013). 


\section{RESULTS AND DISCUSSION}

The sample data were analysed using partial least square-structural equation modelling (PLS-SEM) (Ringle et al., 2014). Two sub-models were considered, i.e., the measurement and the structural model. The measurement model is assessed to evaluate the convergent and discriminant validity while the structural model evaluation examined the proposed hypotheses of this study.

\section{Measurement Model Assessment}

The reliability and validity of the construct are determined through the measurement model. It is assessed by examining scale reliability, convergent validity, and discriminant validity. For the evaluation of convergent validity, Cronbach's $\alpha$, composite reliability (CR), average variance extracted (AVE) scores, and individual factor loadings were considered. The results of convergent validity are presented in Table 3.

Table 3

Measurement model results

\begin{tabular}{lccc}
\hline Constructs & Cronbach's $\alpha$ & CR & AVE \\
\hline A & 0.799 & 0.881 & 0.714 \\
ATT & 0.841 & 0.894 & 0.678 \\
INT & 0.841 & 0.893 & 0.677 \\
PCB & 0.831 & 0.899 & 0.747 \\
RO & 0.900 & 0.926 & 0.716 \\
SC & 0.862 & 0.902 & 0.650 \\
SN & 0.869 & 0.911 & 0.718 \\
\hline
\end{tabular}

Note: $\mathrm{A}=$ awareness of auto ijarah; $\mathrm{ATT}=$ attitude towards auto ijarah; INT $=$ intention to adopt auto ijarah; $\mathrm{PCB}=$ perceived cost-benefits; $\mathrm{RO}=$ religious orientation; $\mathrm{SC}=$ Sharia compliance; $\mathrm{SN}=$ subjective norm

Our results showed that the significance of individual factor loadings is greater than the recommended criteria of 0.55 by Tabachnik and Fidell (2007). Also as shown in Table 3, for each of the constructs the scores of composite reliability satisfy the mentioned criteria by Hair et al. (2011) as all the scores are larger than 0.7. Similarly, for all the constructs, Cronbach's alpha values are greater than 0.60 (Tabachnick \& Fidell, 2007), which indicates the reliability of the employed instrument. For examining the convergent validity, that is the degree to which the assigned indicators well measure the traits, the criterion of Fornell and Larcker (1981) was used. For acceptable convergent validity, the proposed criteria recommend that the AVE values must be greater than 0.5 . 
Table 3 indicates that all the AVE scores are greater than 0.5 , which indicates the fulfilment of convergent validity criteria. The square root of AVE was used for the evaluation of discriminant validity. The recommended criteria by Fornell and Larcker (1981) suggested that for each construct, the square root of AVE should be greater than its inter-construct correlations. It is shown from the correlation matrix in Table 4 that the values in the diagonal signify the square root of AVE and infers that for each construct the values are below the square root of AVE which shows the fulfilment of first criteria of discriminant validity.

Table 4

Fornell and Larcker criterion for discriminant validity

\begin{tabular}{lccccccc}
\hline Constructs & A & ATT & INT & PCB & RO & SC & SN \\
\hline A & $\mathbf{0 . 8 4 5}$ & & & & & & \\
ATT & 0.579 & $\mathbf{0 . 8 2 3}$ & & & & & \\
INT & 0.474 & 0.646 & $\mathbf{0 . 8 2 3}$ & & & & \\
PCB & 0.741 & 0.614 & 0.406 & $\mathbf{0 . 8 6 4}$ & & & \\
RO & 0.692 & 0.721 & 0.561 & 0.693 & $\mathbf{0 . 8 4 6}$ & & \\
SC & 0.679 & 0.653 & 0.542 & 0.726 & 0.750 & $\mathbf{0 . 8 0 6}$ & \\
SN & 0.448 & 0.603 & 0.734 & 0.431 & 0.557 & 0.526 & $\mathbf{0 . 8 4 8}$ \\
\hline
\end{tabular}

Note: The numbers shown in boldface on diagonal represents the square root of AVE; the off-diagonal part represents the correlation values

The cross-loading analysis is shown in Table 5. It indicates that each item on their respective constructs holds higher loading than all cross-loadings. The differences in cross-loadings are above 0.1, as suggested by Gefen and Straub (2005). The items bearing the loading of 0.50 and greater are retained in the present study, which according to Hair et al. (2011), the loading of \pm 0.50 holds statistical significance.

Table 5

Cross loadings analysis

\begin{tabular}{lccccccc}
\hline Constructs & A & ATT & INT & PCB & RO & SC & SN \\
\hline A1 & 0.917 & 0.544 & 0.477 & 0.675 & 0.650 & 0.625 & 0.471 \\
A2 & 0.723 & 0.333 & 0.285 & 0.493 & 0.462 & 0.462 & 0.214 \\
A3 & 0.882 & 0.555 & 0.409 & 0.688 & 0.617 & 0.618 & 0.401 \\
ATT1 & 0.428 & 0.780 & 0.528 & 0.596 & 0.589 & 0.502 & 0.525 \\
ATT2 & 0.488 & 0.857 & 0.523 & 0.514 & 0.640 & 0.550 & 0.453 \\
ATT3 & 0.520 & 0.836 & 0.532 & 0.486 & 0.583 & 0.565 & 0.485 \\
ATT4 & 0.470 & 0.819 & 0.544 & 0.429 & 0.564 & 0.532 & 0.522 \\
\hline
\end{tabular}


Table 5: (continued)

\begin{tabular}{lccccccc}
\hline Constructs & A & ATT & INT & PCB & RO & SC & SN \\
\hline INT1 & 0.333 & 0.529 & 0.801 & 0.358 & 0.474 & 0.434 & 0.706 \\
INT2 & 0.404 & 0.539 & 0.840 & 0.307 & 0.455 & 0.453 & 0.560 \\
INT3 & 0.389 & 0.563 & 0.853 & 0.346 & 0.462 & 0.471 & 0.590 \\
INT4 & 0.441 & 0.492 & 0.796 & 0.322 & 0.451 & 0.423 & 0.544 \\
PCB1 & 0.665 & 0.572 & 0.344 & 0.893 & 0.593 & 0.559 & 0.383 \\
PCB2 & 0.716 & 0.549 & 0.321 & 0.874 & 0.597 & 0.567 & 0.334 \\
PCB3 & 0.550 & 0.476 & 0.381 & 0.825 & 0.602 & 0.737 & 0.392 \\
RO1 & 0.676 & 0.561 & 0.439 & 0.643 & 0.844 & 0.679 & 0.416 \\
RO2 & 0.621 & 0.538 & 0.447 & 0.607 & 0.869 & 0.685 & 0.483 \\
RO3 & 0.592 & 0.646 & 0.498 & 0.593 & 0.889 & 0.653 & 0.481 \\
RO4 & 0.566 & 0.609 & 0.458 & 0.580 & 0.839 & 0.599 & 0.415 \\
RO5 & 0.483 & 0.677 & 0.517 & 0.516 & 0.787 & 0.560 & 0.544 \\
SC1 & 0.537 & 0.529 & 0.379 & 0.647 & 0.526 & 0.774 & 0.365 \\
SC2 & 0.520 & 0.556 & 0.452 & 0.620 & 0.591 & 0.848 & 0.442 \\
SC3 & 0.561 & 0.540 & 0.434 & 0.624 & 0.564 & 0.870 & 0.425 \\
SC4 & 0.552 & 0.522 & 0.426 & 0.565 & 0.569 & 0.856 & 0.416 \\
SC5 & 0.551 & 0.471 & 0.470 & 0.468 & 0.531 & 0.665 & 0.447 \\
SN1 & 0.435 & 0.583 & 0.643 & 0.458 & 0.525 & 0.502 & 0.869 \\
SN2 & 0.375 & 0.512 & 0.612 & 0.401 & 0.476 & 0.437 & 0.858 \\
SN3 & 0.335 & 0.486 & 0.632 & 0.283 & 0.460 & 0.443 & 0.851 \\
SN4 & 0.372 & 0.461 & 0.600 & 0.315 & 0.424 & 0.398 & 0.811 \\
\hline
\end{tabular}

Finally, the results of the heterotrait-monotrait (HTMT) ratio of correlation also signifies the discriminant validity criteria (Table 6). It is indicated that among the values, none of them is greater than 0.9 as suggested by Gold et al. (2001) and Teo et al. (2008).

Table 6

HTMT ratio of correlation

\begin{tabular}{lccccccc}
\hline Constructs & A & ATT & INT & PCB & RO & SC & SN \\
\hline A & & & & & & & \\
ATT & 0.689 & & & & & & \\
INT & 0.566 & 0.767 & & & & & \\
PCB & 0.803 & 0.737 & 0.481 & & & & \\
RO & 0.808 & 0.824 & 0.64 & 0.801 & & & \\
SC & 0.808 & 0.766 & 0.631 & 0.851 & 0.845 & & \\
SN & 0.514 & 0.704 & 0.853 & 0.503 & 0.624 & 0.602 & \\
\hline
\end{tabular}




\section{Structural Model Assessment}

The structural model is assessed to determine the predictive power and analyse the relationships between the hypothesised variables. The structural model results are indicated in Table 7 .

Table 7

Standardised regression weights for the research model

\begin{tabular}{lllcccc}
\hline Hypothesis & Regression path & Effect type & B-coefficients & $p$ values & VIF & Remarks \\
\hline H1 & A $\rightarrow$ INT & Direct effect & 0.111 & 0.100 & 1.49 & Not supported \\
H2 & ATT $\rightarrow$ INT & Direct effect & 0.285 & 0.000 & 1.56 & Supported \\
H3 & PCB $\rightarrow$ INT & Direct effect & -0.176 & 0.013 & 1.77 & Supported \\
H4 & RO $\rightarrow$ INT & Direct effect & 0.028 & 0.071 & 1.65 & Supported \\
H5 & SC $\rightarrow$ INT & Direct effect & 0.120 & 0.060 & 1.70 & Supported \\
H6 & SN $\rightarrow$ INT & Direct effect & 0.510 & 0.000 & 1.19 & Supported \\
\hline
\end{tabular}

Note $:$ VIF $=$ variance inflation factor

As shown in Table 7, the regression path A $\rightarrow$ INT is insignificant and implies that $\mathrm{H} 1$ is not accepted and does not fall in the significance level $(\beta=0.111$, $p>0.1$ ), it examines the effect of awareness of auto ijarah on customers intention. It is assumed that awareness about ijarah financing and its features results in high usage intentions.

The regression path ATT $\rightarrow$ INT is significant which implies that $\mathrm{H} 2$ is accepted and lying in the significance level $(\beta=0.285, p<0.1)$. The effect of attitude towards ijarah on customers intentions was examined. It is assumed that a positive attitude results in higher usage intentions. Furthermore, it is indicated from the statistical results that $\mathrm{PCB} \rightarrow \mathrm{INT}$ is significant and implies that $\mathrm{H} 3$ is accepted, and it lies in the significance level $(\beta=-0.176, p<0.1)$, it examines the effect of perceived cost-benefits analysis conducted by customers on their intentions to select ijarah for their auto financing needs. The higher the perception of attaining cost benefits, the higher will be the intention of customers to select ijarah as their auto financing mode.

Moreover, the regression path RO $\rightarrow$ INT is also significant and implies that H4 is accepted and lies in the significance level $(\beta=0.028, p<0.1)$. It is assumed that the orientation of customers towards religious beliefs and values inclined them towards the adoption of auto ijarah. The regression path of SC $\rightarrow$ INT is significant and implies that H5 is accepted and lies in the significance level 
$(\beta=0.120, p<0.1)$. Likewise, it is shown from the regression path of $\mathrm{SN} \rightarrow$ INT that $\mathrm{H} 6$ is accepted and lies in the significance level $(\beta=0.510, p<0.1)$. The study also addressed the problem of multicollinearity in the structural model. As reported in Table 7, all VIF values are less than the benchmark of 10; hence our model is free from multicollinearity issue.

\section{CONCLUSION AND PRACTICAL IMPLICATIONS}

In Pakistan, Islamic banking has been growing at a rapid pace since its inception. Thus, by keeping in view the emerging industry of Islamic banks in Pakistan, the present study attempts to analyse the factors that account for the customers' adoption of auto ijarah. Primary data was conveniently drawn from the potential customers of Islamic banks of Pakistan. The structured questionnaire was used as a data collection tool based on scales adapted from the literature. The proposed research framework is based on the TRA model which emphasised the determinants of behavioural intentions of an individual. It was postulated that awareness of auto ijarah among customers, their attitude towards ijarah financing, religious orientation, the compliance of Sharia rules, social influence, and the analysis of cost and benefits determine customers intentions to use auto ijarah. The results revealed that customers' positive attitude towards auto ijarah, their religious orientation, the perception of gaining cost-benefit from ijarah transaction, and social influence to use Islamic financing resulted in the strong intentions to adopt auto ijarah. Furthermore, the beliefs of customers regarding the compliance of Sharia rules in the product structure of ijarah contribute towards the adoption of auto ijarah. Whereas it is found that the awareness of auto ijarah solely is not a determining factor of usage intention.

This study provides some useful and beneficial policy to Islamic bank managers. Our findings recommend that Islamic bank policymakers enhance auto ijarah financing visibility through various social networking channels such as Facebook, Twitter, and other digital forums. It is also important to disseminate the information and answer the queries about auto ijarah among the customers. Since auto ijarah is a Sharia compliance product, it is important to educate Islamic bank customers about its mechanism. This will help Islamic banks to gain more customers and market share in the business. Additionally, Islamic bank managers may execute auto ijarah financing by telling the customers about its unique features, benefits, and accessibility. Practically, Islamic bank policymakers may use the results of this study to understand the customers intention to adopt auto ijarah and plan the strategies based on our study recommendations. 
On the other side, this study used a well-established theoretical framework of TRA, therefore, we recommend upcoming studies to adopt other theoretical assumptions to extend our research such as theory of planned behaviour and diffusion of innovation.

This study contributes significantly to the existing literature of Islamic banking both theoretically and methodologically. Very few studies have been conducted to assess auto ijarah and customer's intention in Pakistan using the TRA model to our best knowledge. Our literature review section has highlighted the importance and relevance of the TRA model, particularly in predicting customer's intention. Amin (2013) and Ali et al. (2017a) supported our arguments and stated that the TRA model's adoption would produce a better explanation about the acceptance of customers towards Islamic products. Similarly, this study's empirical findings validated the assumptions of the TRA model in the context of auto ijarah financing. On the other side, we employed PLS-SEM assumptions to test our hypothesised model. This signifies that our results are robust and reliable under the up-to-date statistical approach. Therefore, we laid the foundation for upcoming studies to use advanced statistical techniques to examine Islamic banking studies on customer behaviour.

\section{NOTES}

1. Retrieved 15 September 2020 from https://www.dummies.com/personal-finance/ islamic-finance/islamic-finance-for-dummies-cheat-sheet/

2. Retrieved 15 September 2020 from http://www.sbp.org.pk/ibd/bulletin/2018/Mar.pdf

3. Retrieved 2 January 2021 from https://invest.gov.pk/automobiles

4. Retrieved 2 January 2021 from https://invest.gov.pk/automobiles\#gallery and http://pbit.gop.pk/system/files/Auto\%20Sector.pdf

\section{REFERENCES}

Ahmad, W. M. W., Rahman, A. A., Ali, N. A., \& Seman, A. C. (2008). Religiosity and banking selection criteria among Malays in Lembah Klang. Shariah Journal, 16(2), 279-304.

Ahmadova, L. E. O. (2019). Global Islamic economy: Current state and future perspectives. 2. ERASMUS Uluslararası Akademik Araştırmalar Sempozyumu, 1-289.

Ajzen, I., \& Fishbein, M. (1977). Attitude-behavior relations: A theoretical analysis and review of empirical research. Psychological Bulletin, 84, 888-918. https://doi .org/10.1037/0033-2909.84.5.888 
Al-Balushi, Y., Locke, S., \& Boulanouar, Z. (2019). Determinants of the decision to adopt Islamic finance: Evidence from Oman. ISRA International Journal of Islamic Finance, 11(1), 6-26. https://doi.org/10.1108/IJIF-02-2018-0020

Al-Ajmi, J., Abo Hussain, H., \& Al-Saleh, N. (2009). Clients of conventional and Islamic banks in Bahrain: How they choose which bank to patronize. International Journal of Social Economics, 36(11), 1086-1112. https://doi.org/ 10.1108/03068290910992642

Al-Somali, S. A., Gholami, R., \& Clegg, B. (2009). An investigation into the acceptance of online banking in Saudi Arabia. Technovation, 29(2), 130-141. https://doi .org/10.1016/j.technovation.2008.07.004

Ali, M., Raza, S. A., \& Chin-Hong, P. (2015). Factors affecting intention to use Islamic personal financing in Pakistan: Evidence from the modified TRA model. MPRA paper number 66023, University Library of Munich, Germany.

Ali, M., \& Raza, S. A. (2017). Service quality perception and customer satisfaction in Islamic banks of Pakistan: The modified SERVQUAL model. Total Quality Management \& Business Excellence, 28(5-6), 559-577. https://doi.org/10 $.1080 / 14783363.2015 .1100517$

Ali, M., Raza, S. A., \& Puah, C. H. (2017a). Factors affecting to select Islamic credit cards in Pakistan: The TRA model. Journal of Islamic Marketing, 8(3), 330-344. https://doi.org/10.1108/JIMA-06-2015-0043

Ali, M., Raza, S. A., Puah, C. H., \& Karim, M. Z. A. (2017b). Islamic home financing in Pakistan: A SEM-based approach using modified TPB model. Housing Studies, 32(8), 1156-1177. https://doi.org/10.1080/02673037.2017.1302079

Amin, H. (2013). Factors influencing Malaysian bank customers to choose Islamic credit cards. Journal of Islamic Marketing, 4(3), 245-263. https://doi.org/10.1108/ JIMA-02-2012-0013

Amin, H., Abdul-Rahman, A. R., \& Abdul Razak, D. (2014a). Theory of Islamic consumer behaviour: An empirical study of consumer behaviour of Islamic mortgage in Malaysia. Journal of Islamic Marketing, 5(2), 273-301. https://doi.org/10.1108/ JIMA-06-2013-0042

Amin, H., Hamid, M. R. A., Lada, S., \& Anis, Z. (2008). The adoption of mobile banking in Malaysia: The case of Bank Islam Malaysia Berhad (BIMB). International Journal of Business and Society, 9(2), 69-86.

Amin, H., Rahim Abdul Rahman, A., \& Abdul Razak, D. (2014b). Consumer acceptance of Islamic home financing. International Journal of Housing Markets and Analysis, 7(3), 307-332. https://doi.org/10.1108/IJHMA-12-2012-0063

Amin, H., Rahim Abdul Rahman, A., Laison Sondoh Jr, S., \& Magdalene Chooi Hwa, A. (2011). Determinants of customers' intention to use Islamic personal financing: The case of Malaysian Islamic banks. Journal of Islamic Accounting and Business Research, 2(1), 22-42.

Awan, A. G., \& Azhar, M. (2014). Consumer behavior towards Islamic banking in Pakistan. European Journal of Accounting Auditing and Finance Research, 2(9), 42-65. 
Aziz, Y. A., \& Chok, N. V. (2013). The role of Halal awareness, Halal certification, and marketing components in determining Halal purchase intention among nonMuslims in Malaysia: A structural equation modeling approach. Journal of International Food \& Agribusiness Marketing, 25(1), 1-23. https://doi.org/10.10 80/08974438.2013.723997

Bananuka, J., Kaawaase, T. K., Kasera, M., \& Nalukenge, I. (2019). Determinants of the intention to adopt Islamic banking in a non-Islamic developing country: The case of Uganda. ISRA International Journal of Islamic Finance, 11(2), 166-186. https://doi.org/10.1108/IJIF-04-2018-0040

Bashir, M. S. (2013). Analysis of customer satisfaction with the Islamic banking sector: The case of Brunei Darussalam. Asian Journal of Business and Management Sciences, 2(10), 38-50.

Bhatti, M. (2020a). Resolving Islamic finance disputes through arbitration in the Middle East. In H. Mohi-ud-Din Qadri, \& M. I. Bhatti (Eds.), The growth of Islamic finance and banking: Innovation, governance and risk mitigation (pp. 254-261). London: Routledge. https://doi.org/10.4324/9780429262432

Bhatti, M. (2020b). Managing Shariah non-compliance risk via Islamic dispute resolution. Journal of Risk and Financial Management, 13(1), 2-9. https://doi.org/10.3390/ jrfm13010002

Bhatti, T., \& Md Husin, M. (2019). An investigation of the effect of customer beliefs on the intention to participate in family Takaful schemes. Journal of Islamic Marketing, 11(3), 709-727. https://doi.org/10.1108/JIMA-04-2018-0066

Bizri, R. M. (2014). A study of Islamic banks in the non-GCC MENA region: Evidence from Lebanon. International Journal of Bank Marketing, 32(2), 130-149. https://doi.org/10.1108/IJBM-04-2013-0035

Buchari, I., Rafiki, A., \& Al Qassab, M. A. H. (2015). Awareness and attitudes of employees towards Islamic banking products in Bahrain. Procedia Economics and Finance, 30, 68-78. https://doi.org/10.1016/S2212-5671(15)01256-3

Chang, M. (1998). Predicting unethical behavior: A comparison of the theory of reasoned action of the theory of planned behavior. Journal of Business Ethics, 17(16), 1825-1833. https://doi.org/10.1023/A:1005721401993

Chau, P. Y., \& Hu, P. J. H. (2001). Information technology acceptance by individual professionals: A model comparison approach. Decision Sciences, 32(4), 699-719. https://doi.org/10.1111/j.1540-5915.2001.tb00978.x

Chaudhury, M. A., \& Bhatti, M. I. (2017). Heterodox Islamic economics: The emergence of an ethico-economic theory. United Kingdom: Routledge. https://oi.org/ $10.4324 / 9781315660172$

Chapra, I. U., Ahmed, A., Rehan, R., \& Hussain, F. (2018). Consumer's preference and awareness: Comparative analysis between conventional and Islamic ijarah auto financing in Pakistan. Al-Iqtishad Journal of Islamic Economics, 10(2), 389-402. https://doi.org/10.15408/aiq.v10i2.7106

Churchill Jr., G. A. (1979). A paradigm for developing better measures of marketing constructs. Journal of Marketing Research, 16(1), 64-73. https://doi.org/10 $.1177 / 002224377901600110$ 
Comrey, A. L., \& Lee, H. B. (1992). Interpretation and application of factor analysis results. In A. L. Comrey, \& H. B. Lee (Eds.), A first course in factor analysis (vol. 2, pp. 250-254). New York: Psychology Press.

Ehsan Wahla, A., Hasan, H., \& Bhatti, M. I. (2018). Measures of customers' perception of car ijarah financing. Journal of Islamic Accounting and Business Research, 9(1), 2-16. https://doi.org/10.1108/JIABR-10-2015-0051

Farhat, K., Aslam, W., \& Sany Sanuri, B. M. M. (2019). Predicting the intention of generation $\mathrm{M}$ to choose family takaful and the role of halal certification. Journal of Islamic Marketing, 10(3),724-742. https://doi.org/10.1108/JIMA-122017-0143

Fishbein, M., \& Ajzen, I. (1975). Belief, attitude, intention, and behavior: An introduction to theory and research. Reading, MA: Addison-Wesley.

Fishbein, M., Jaccard, J., Davidson, A. R., Ajzen, I., \& Loken, B. (1980). Predicting and understanding family planning behaviors. Understanding Attitudes and Predicting Social Behavior. Prentice-Hall.

Fornell, C., \& Larcker, D. F. (1981). Structural equation models with unobservable variables and measurement error: Algebra and statistics. Journal of Marketing Research, 18(3), 382-388. https://doi.org/10.1177/002224378101800313

Gefen, D., \& Straub, D. (2005). A practical guide to factorial validity using PLS-Graph: Tutorial and annotated example. Communications of the Association for Information Systems, 16(1), 5-16. https://doi.org/10.17705/1CAIS.01605

Gold, A. H., Malhotra, A., \& Segars, A. H. (2001). Knowledge management: an organizational capabilities perspective. Journal of Management Information Systems, 18(1), 185-214. https://doi.org/10.1080/07421222.2001.11045669

Gopi, M., \& Ramayah, T. (2007). Applicability of theory of planned behavior in predicting intention to trade online: Some evidence from-a developing country. International Journal of Emerging Markets, 2(4), 348-360. https://doi.org/10 $.1108 / 17468800710824509$

Gumel, A. M., Othman, M. A., \& Yusof, R. M. (2015). Critical insights into an integrated literature review on customers' adoption of Islamic banking research. International Journal of Scientific Research and Innovative Technology, 2(6), 45-57.

Hair, J. F., Ringle, C. M., \& Sarstedt, M. (2011). PLS-SEM: Indeed a silver bullet. Journal of Marketing Theory and Practice, 19(2), 139-152. https://doi.org/10.2753/ MTP1069-6679190202

Hanif, F., Khan Alwi, S. K., \& Shamshir, M. (2020a). House financing by Islamic banks: Incidence in the province of Sindh-Pakistan. New Horizon, 14(1), 199-212.

Hanif, F., Shamshir, M., \& Alwi, K. K. (2020b). House finance for low-income groups in Pakistan. Independent Journal of Management \& Production, 11(4), 1394-1418. https://doi.org/10.14807/ijmp.v11i4.1042

Hassan, H. A., \& Abbas, S. K. (2019). Factors influencing the investors' intention to adopt Takaful (Islamic insurance) products: A survey of Pakistan. Journal of Islamic Marketing, 11(1), 1-13. https://doi.org/10.1108/JIMA-03-2018-0064 
Hoque, M. E., Hassan, M. K., Hashim, N. M. H. N., \& Zaher, T. (2019). Factors affecting Islamic banking behavioral intention: The moderating effects of customer marketing practices and financial considerations. Journal of Financial Services Marketing, 24(1-2), 44-58. https://doi.org/10.1057/s41264-019-00060-x

Islam, J. U., \& Rahman, Z. (2017). Awareness and willingness towards Islamic banking among Muslims: An Indian perspective. International Journal of Islamic and Middle Eastern Finance and Management, 10(1), 92-101. https://doi.org/10 .1108/IMEFM-01-2016-0017

Jaffar, M. A., \& Musa, R. (2016). Determinants of attitude and intention towards Islamic financing adoption among non-users. Procedia Economics and Finance, 37, 227-233. https://doi.org/10.1016/S2212-5671(16)30118-6

Jamshidi, D., \& Hussin, N. (2018). An integrated adoption model for Islamic credit card: PLS-SEM based approach. Journal of Islamic Accounting and Business Research, 9(3), 308-335. https://doi.org/10.1108/JIABR-07-2015-0032

Kaakeh, A., Hassan, M. K., \& Van Hemmen Almazor, S. F. (2019). Factors affecting customers' attitude towards Islamic banking in the UAE. International Journal of Emerging Markets, 14(4), 668-688. https://doi.org/10.1108/IJOEM-11-2017 $-0502$

Kaawaase, T. K., \& Nalukwago, L. (2017). Religiosity and Islamic banking in Uganda. Makerere Business Journal, 13(1), 70-93. https://doi.org/10.33117/513

Khan, M. M., \& Bhatti, M. I. (2008). Development in Islamic banking: A financial risk-allocation approach. The Journal of Risk Finance, 9(1), 40-51. https://doi. org/10.1108/15265940810842401

Khan, Z. A., Azam, M., \& Agha, S. E. (2019). Security deposit issues in ijārah financing: Evidence from the Islamic banks of Pakistan. Turkish Journal of Islamic Economics, 6(2), 44-61. https://doi.org/10.26414/A059

Lada, S., Harvey Tanakinjal, G., \& Amin, H. (2009). Predicting intention to choose halal products using theory of reasoned action. International Journal of Islamic and Middle Eastern Finance and Management, 2(1), 66-76. https://doi.org/ 10.1108/17538390910946276

Lee, K. H., \& Ullah, S. (2011). Customers' attitude toward Islamic banking in Pakistan. International Journal of Islamic and Middle Eastern Finance and Management, 4(2), 131-145. https://doi.org/10.1108/17538391111144524

Lewis, W., Agarwal, R., \& Sambamurthy, V. (2003). Sources of influence on beliefs about information technology use: An empirical study of knowledge workers. MIS Quarterly, 27(4), 657-678. https://doi.org/10.2307/30036552

Mansour, I. H. F., Eljelly, A. M., \& Abdullah, A. M. (2016). Consumers' attitude towards e-banking services in Islamic banks: The case of Sudan. Review of International Business and Strategy, 26(2), 244-260. https://doi.org/10.1108/RIBS-02-2014 $-0024$

Metwally, M. (1996). Attitudes of Muslims towards Islamic banks in a dual-banking system. American Journal of Islamic Finance, 6(1), 11-17.

Nawi, F. A. M., Yazid, A. S., \& Mohammed, M. O. (2013). A critical literature review for Islamic banks selection criteria in Malaysia. International Business Research, 6(6), 143-151. https://doi.org/10.5539/ibr.v6n6p143 
Omer, H. (1992). The implication of Islamic beliefs and practice on Islamic financial institutions in the UK. Unpublished $\mathrm{PhD}$ dissertation, Loughborough University, Loughborough.

Othman, A., \& Owen, L. (2001). Adopting and measuring customer service quality (SQ) in Islamic banks: A case study in Kuwait finance house. International Journal of Islamic Financial Services, 3(1), 1-26.

Pelling, E. L., \& White, K. M. (2009). The theory of planned behavior applied to young people's use of social networking web sites. Cyberpsychology \& Behavior, 12(6), 755-759. https://doi.org/10.1089/cpb.2009.0109

Ramayah, T., Jantan, M., Mohd Noor, M. N., Razak, R. C., \& Koay, P. L. (2003). The receptiveness of internet banking by Malaysian consumers: The case of Penang. Asian Academy of Management Journal, 8(2), 1-29.

Ramli, M. F., Rahman, M. A., \& Chauhan, A. (2018). Assessing the antecedents of usage intention on Islamic banking products in dual banking. Advanced Science Letters, 24(1), 482-484. https://doi.org/10.1166/asl.2018.12045

Raza, S. A., Ahmed, R., Ali, M., \& Qureshi, M. A. (2019). Influential factors of Islamic insurance adoption: An extension of theory of planned behavior. Journal of Islamic Marketing, 11(6), 1497-1515. https://doi.org/10.1108/JIMA-03-2019 $-0047$

Razak, D. A., \& Abduh, M. (2012). Customers' attitude towards diminishing partnership home financing in Islamic banking. American Journal of Applied Science, 9(4), 593-599. https://doi.org/10.3844/ajassp.2012.593.599

Razi, N. (2014). The Islamic banking system and mode of leasing: A comparative analysis in the light of Maqasid al-Shari'ah. Cultural and Religious Studies, 2(6), 349359. https://doi.org/10.17265/2328-2177/2014.06.005

Reich, K. H., Oser, F. K., \& Scarlett, W. G. (Eds.). (1999). Psychological studies on spiritual and religious development: The case of religion, vol. 2. Lengerich: Pabst Science Publishers.

Rezai, G., Teng, P. K., Mohamed, Z., \& Shamsudin, M. N. (2012). Consumers' awareness and consumption intention towards green foods. African Journal of Business Management, 6(12), 4496-4503. https://doi.org/10.5897/AJBM11.1414

Ringle, C. M., Wende, S., \& Becker, J. M. (2014). SmartPLS 3. Hamburg: SmartPLS. Academy of Management Review, 9, 419-445.

Saqib, L., Farooq, M. A., \& Zafar, A. M. (2016). Customer perception regarding Sharī 'ah compliance of Islamic banking sector of Pakistan. Journal of Islamic Accounting and Business Research, 7(4), 282-303. https://doi.org/10.1108/ JIABR-08-2013-0031

Souiden, N., \& Rani, M. (2015). Consumer attitudes and purchase intentions toward Islamic banks: The influence of religiosity. International Journal of Bank Marketing, 33(2), 143-161. https://doi.org/10.1108/IJBM-10-2013-0115

Sulaiman, M. (2003). The influence of riba and zakat on Islamic accounting. Indonesian Management and Accounting Review, 2(2), 149-167.

Tabachnik, B. G., \& Fidell, S. L. (2007). Using multivariate statistics (5th ed.). Boston: Pearson Education Inc. 
Taib, F. M.., Ramayah, T., \& Abdul Razak, D. (2008). Factors influencing the intention to use diminishing partnership home financing. International Journal of Islamic and Middle Eastern Finance and Management, 1(3), 235-248. https://doi. org/10.1108/17538390810901168

Taqi, U. M. M. (2000). An introduction to Islamic finance. Karachi, Pakistan: ldaratul Maarif.

Tenga, P. K., Owb, M. W., Sandhuc, S. K., \& Kassima, U. K. (2018). Green attitude and purchase intention towards the environmental-friendly product. Journal of Emerging Economies \& Islamic Research, 6(1), 17-25. https://doi.org/10.24191/ jeeir.v6i1.8770

Teo, T. S. H., Srivastava, S. C., \& Jiang, L. (2008). Trust and electronic government success: An empirical study. Journal of Management Information Systems, 25(3), 99-132. https://doi.org/10.2753/MIS0742-1222250303

Usmani, M. T. (2001). An introduction to Islamic finance. Netherlands: Brill. https://doi .org/10.1163/9789004479913

Venkatesh, V., \& Davis, F. D. (2000). A theoretical extension of the technology acceptance model: Four longitudinal field studies. Management Science, 46(2), 186-204. https://doi.org/10.1287/mnsc.46.2.186.11926

Wajdi Dusuki, A., \& Irwani Abdullah, N. (2007). Why do Malaysian customers patronise Islamic banks? International Journal of Bank Marketing, 25(3), 142-160. https://doi.org/10.1108/02652320710739850

Yaseen, S. G., \& El Qirem, I. A. (2018). Intention to use e-banking services in the Jordanian commercial banks. International Journal of Bank Marketing, 36(3), 557-571. https://doi.org/10.1108/IJBM-05-2017-0082

Yulihasri, T. (2004). Retailing on internet: The buying intention. Unpublished MBA thesis, Universiti Sains Malaysia, Pulau Pinang. 